\title{
Movements of Subadult Male Grizzly Bears, Ursus arctos, in the Central Canadian Arctic
}

\author{
Robert J. Gau ${ }^{1}$, Philip D. Mcloughlin ${ }^{2}$, Ray CAse $^{1}$, H. Dean ClufF ${ }^{3}$, Robert Mulders ${ }^{1}$, and \\ FRANÇOIS MESSIER ${ }^{2}$
}

${ }^{1}$ Wildlife and Fisheries Division, Department of Resources, Wildlife and Economic Development, Government of the Northwest Territories, \#600 5102-50th Avenue, Yellowknife, Northwest Territories X1A 3S8 Canada; e-mail: rob_gau@ gov.nt.ca ${ }^{2}$ Department of Biology, University of Saskatchewan, 112 Science Place, Saskatoon, Saskatchewan S7N 5E2 Canada

${ }^{3}$ Department of Resources, Wildlife, and Economic Development, Government of the Northwest Territories, North Slave Region, P.O. Box 2668, Yellowknife, Northwest Territories X1A 2P9 Canada

Gau, Robert J., Philip D. McLoughlin, Ray Case, H. Dean Cluff, Robert Mulders, and François Messier. 2004. Movements of subadult male Grizzly Bears, Ursus arctos, in the central Canadian Arctic. Canadian Field-Naturalist 118(2): 239-242.

Between May 1995 and June 1999, we equipped eight subadult male (3-5 yrs old) Grizzly Bears (Ursus arctos) with satellite radio-collars within a study area of $235000 \mathrm{~km}^{2}$, centred $400 \mathrm{~km}$ northeast of Yellowknife, Northwest Territories, Canada. Subadult male annual home ranges were extraordinarily large (average $=11407 \mathrm{~km}^{2}, \mathrm{SE}=3849$ ) due, in part, to their movement's occasional linear directionality. We believe their long-range linear movements may reflect some individuals tracking the migration of Caribou (Rangifer tarandus). Seasonal daily movement patterns were similar to adult males that were previously reported. The areas used by these bears are the largest ranges reported for any Grizzly Bears and the scale of their movements may put individual bears in contact with humans even when developments are hundreds of kilometres from the central home range of an animal.

Key Words: Grizzly Bear, Ursus arctos, home range, movements, subadult, central Arctic, Northwest Territories.

The population of Barren-ground Grizzly Bears (Ursus arctos) in the Northwest Territories (NWT) exists at a low density in the tundra and is considered "sensitive" after a recent species-at-risk assessment (Government of the NWT, 2000). As such, there is concern for any increase in human presence that might impact on their numbers.

Economic activity in the central Arctic of the NWT and Nunavut increased dramatically in the early 1990s with the discovery of diamonds. At present there are three mines (two diamond, one gold) and numerous base-metal, gold, and other diamond developments in the region. To address the effects of these developments, in 1995 the Government of the NWT and the University of Saskatchewan initiated the first multifaceted research program into the ecology of Barrenground Grizzly Bears inhabiting the central Arctic.

One aspect of our research program was to detail the spatial requirements of the Barren-ground Grizzly Bears in this region (McLoughlin 2000). However, incidental to our primary objectives, we obtained data on large-scale movements of some subadult male bears (3-5 yrs old) that were also captured and monitored. Although many aspects of bear ecology have been well documented, descriptions of dispersal and movement patterns for subadult Grizzly Bears remain rare and difficult to obtain (McLellan and Hovey 2001). While progress with DNA analysis may shed insights on subadult dispersal in the future (see Waits et al. 1999; Woods et al. 1999; Woods and Strobeck 2000), current methods to examine dispersal in bears generally re- quire marking young animals to identify when captured or killed at a later date, or radio tracking 2- and 3-year olds captured prior to or immediately following separation from their mother. Our findings parallel and complement McLoughlin et al. (1999) and McLoughlin et al. (2003).

\section{Methods}

The study area was centred in Canada's central Arctic $\left(66^{\circ} 10^{\prime} \mathrm{N}, 111^{\circ} 25^{\prime} \mathrm{W}\right)$, encompassing approximately $235000 \mathrm{~km}^{2}$ of mainland Nunavut and the NWT (Figure 1). The study area was delineated by the community of Kugluktuk, the Kent Peninsula, Aylmer Lake, Mackay Lake, and Great Bear Lake. We previously noted the biophysical characteristics of the region in Gau et al. (2002).

Between May 1995 and June 1999, helicopters were used to search for and capture bears. Bears weighing $>110 \mathrm{~kg}$ (males) and $>90 \mathrm{~kg}$ (females) were fitted with tracking devices. There were the minimum weights we considered bears robust enough to wear a collar safely. We considered most two- and three-year-old bears too small and growing too rapidly to be fitted with satellite collars. Some telemetry methods (e.g., inserts or breakaways to collar belting, ear-tag transmitters, expandable radio-collars) show promise; however, improvements are still needed (Costello et al. 2001).

Satellite (Service Argos Inc., Landover, Maryland, USA) and conventional VHF radio-telemetry (Telonics Ltd., Mesa, Arizona, USA) were used to obtain spatial information on Barren-ground Grizzly Bears. Most 
TABLE 1. Subadult male Grizzly Bears, and their periods of long-range ( $>200 \mathrm{~km}$ ) linear directional movement, captured and collared between 1995 and 1999 in the central Canadian Arctic.

\begin{tabular}{|c|c|c|c|c|c|c|c|c|c|c|}
\hline \multirow[b]{2}{*}{ Bear } & \multirow[b]{2}{*}{ Age } & \multirow[b]{2}{*}{ Year } & \multirow{2}{*}{$\begin{array}{c}\text { Number } \\
\text { of } \\
\text { locations }\end{array}$} & \multirow{2}{*}{$\begin{array}{l}95 \% \text { fixed } \\
\text { kernal } \\
\text { range }\left(\mathrm{km}^{2}\right)\end{array}$} & \multicolumn{4}{|c|}{ Mean Daily Movement (km/day) } & \multicolumn{2}{|c|}{ Linear Directional Movements } \\
\hline & & & & & Spring & Summer & $\begin{array}{c}\text { Late } \\
\text { summer }\end{array}$ & Autumn & $\begin{array}{c}\text { Distance } \\
\text { covered }(\mathrm{km})\end{array}$ & $\begin{array}{l}\text { Number } \\
\text { of days }\end{array}$ \\
\hline G595 & 4 & 1995 & 103 & 15899 & 7.5 & 10.4 & 6.2 & 7.9 & 539 & 57 \\
\hline G600 & 3 & 1995 & 129 & 22007 & 16.6 & 8.8 & 10.5 & 7.7 & 779 & 59 \\
\hline G612 & 4 & 1995 & 91 & 4448 & 24.8 & 9.7 & 4.0 & 11.7 & $\begin{array}{l}471 \\
446\end{array}$ & $\begin{array}{l}23 \\
33\end{array}$ \\
\hline G618 & 5 & 1995 & 66 & 4540 & 6.1 & 6.7 & 9.5 & 5.6 & & \\
\hline G656 & 5 & 1996 & 45 & 32188 & $\mathrm{n} / \mathrm{a}^{1}$ & $\mathrm{n} / \mathrm{a}^{1}$ & $\mathrm{n} / \mathrm{a}^{1}$ & $\mathrm{n} / \mathrm{a}^{1}$ & $\begin{array}{l}273 \\
305\end{array}$ & $\begin{array}{l}26 \\
40\end{array}$ \\
\hline G657 & 5 & 1996 & 42 & 6162 & $\mathrm{n} / \mathrm{a}^{1}$ & $\mathrm{n} / \mathrm{a}^{1}$ & $\mathrm{n} / \mathrm{a}^{1}$ & $\mathrm{n} / \mathrm{a}^{1}$ & & \\
\hline G689 & 4 & 1998 & 58 & 3662 & $\mathrm{n} / \mathrm{a}^{1}$ & $\mathrm{n} / \mathrm{a}^{1}$ & $\mathrm{n} / \mathrm{a}^{1}$ & $\mathrm{n} / \mathrm{a}^{1}$ & & \\
\hline G700 & 4 & 1998 & 64 & 2349 & 7.9 & 5.9 & 4.2 & 5.1 & 201 & 32 \\
\hline
\end{tabular}

${ }^{1}<8$ locations/season in every season of the year were recorded thus omitted from analysis.

collars were designed to transmit approximately 2-5 latitude-longitude locations every two days (8-hour duty cycle) from 1 May to 1 November.

Our calculations and techniques for study of animals, ranges from satellite telemetry locations and rates of movement $(\mathrm{km} /$ day $)$ were previously described in McLoughlin et al. (1999) and McLoughlin et al. (2003). Annual home ranges were determined using the 95\% isopleth for bears only with $\geq 38$ locations, so as not to overestimate range size with smaller sample sizes (Seaman et al. 1999). Also, only those animals that transmitted $\geq 8$ locations/season in every season of the year were included for analysis. We defined seasons according to changes in the diet of Barren-ground Grizzly Bears during the active period (adapted from Gau et al. 2002), including spring (den emergence20 June), summer (21 June-31 July), late-summer (1 August-9 September), and autumn (10 Septemberden entrance).

\section{Results}

Of the male bears that were not in a family group with their mother, 6 of the 45 males handled were too small for collaring. However, we did collar and monitor 8 subadult males between 3 and 5 years of age out of a sample of 39 collared males (Table 1). Male subadult movements were extraordinarily large and annual home range averaged $11407 \mathrm{~km}^{2}(\mathrm{SE}=3849$, range $2349-32188$ ).

A unique feature of the subadult movements we observed consisted of periods of long-range ( $>200 \mathrm{~km})$ linear directional forays. Five of the eight subadults we followed exhibited this linear movement pattern. For example, 4-year-old bear G612 in 1995 moved $471 \mathrm{~km}$ from 31 May to 22 June along a northerly trek from the treeline to the Arctic coast. While the other movements may not be as dramatic as G612 in terms of time a distance was covered, long-range linear directional movement appeared common for subadult males in this Barren-ground Grizzly population. Bears G595, G600, G612, and G656 had linear directional movements in the spring; additionally, bears G612, G656, and G700 had autumn linear directional movements.

The subadult males followed a seasonal daily movement pattern similar to adult males (see McLoughlin et al. 1999). Only five bears met our criteria to investigate seasonal movements. Means were $12.6 \mathrm{~km} / \mathrm{d}$ $(\mathrm{SE}=3.6), 8.3 \mathrm{~km} / \mathrm{d}(\mathrm{SE}=0.9), 6.9 \mathrm{~km} / \mathrm{d}(\mathrm{SE}=1.3)$, and $7.6 \mathrm{~km} / \mathrm{d}(\mathrm{SE}=1.2)$ for spring, summer, late summer, and autumn, respectively. There was a clear general trend from a high rate of movement (spring) to lower rates for the rest of their active period, although an ANOVA determined no significant differences between seasonal means $\left(F_{3,16}=1.6, P=0.2\right)$.

\section{Discussion}

The annual ranges of adult and subadult Barrenground Grizzly Bears in the central Canadian Arctic are the largest ranges yet reported for grizzlies in North America (see Table 1, McLoughlin et al. 1999). However, there are very few published data about subadult Grizzly Bear movement patterns either to refute or support our claim (McLellan and Hovey 2001). Jonkel (1987), along with Mace and Waller (1997), noted that dispersing immature brown bears tended to have smaller home ranges than adult male bears. However, LeFranc et al. (1987), along with Nagy et al. (1983), summarized examples where subadults, believed dispersing from maternal home ranges, had home ranges as large or larger than those of adult males. Regardless, the magnitude of the movement patterns we observed eclipses other results that have been previously published.

We have gleaned valuable insights into the movement patterns of Canadian Barren-ground Grizzly Bears. Mean annual ranges were $7245 \mathrm{~km}^{2}$ for adult males and $2100 \mathrm{~km}^{2}$ for females, with no difference in 


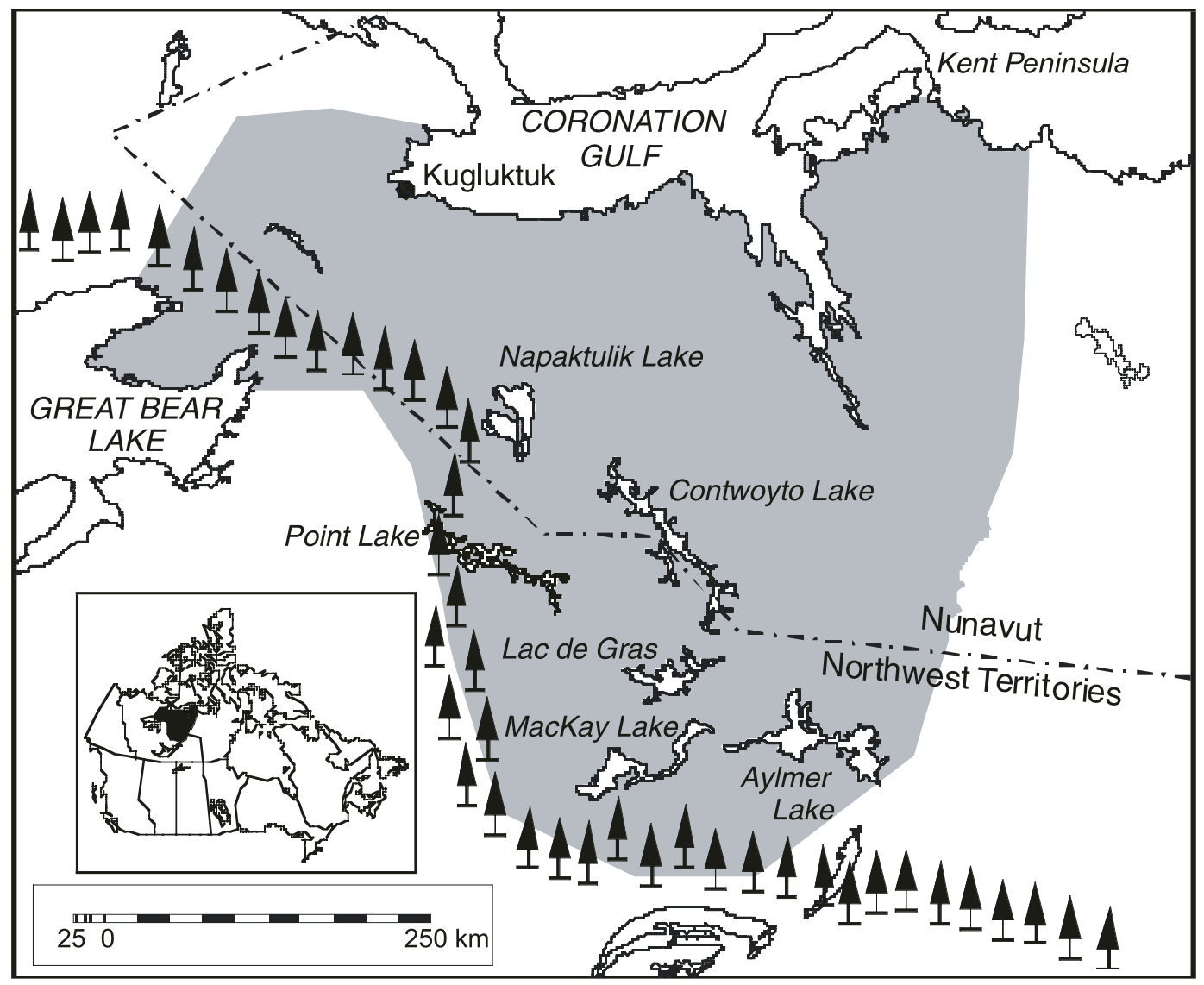

FIGURE 1. Location of the study area in Canada's central Arctic. The treeline indicates the approximate northern limit of coniferous forest in the region.

the ranges for females of differing family status (McLoughlin et al. 2003). The large disparity between adult males and females $\left(5145 \mathrm{~km}^{2}\right)$, and especially between subadult males and females $\left(9307 \mathrm{~km}^{2}\right)$, is interesting since females introduce younger male bears only to a seemingly small portion of the land they will eventually use in the central Arctic. Although we can expect a high degree of movement and population overlap among males in the central Arctic (McLoughlin et al. 2002), it is possible that some of the subadult male ranges we recorded were somewhat inflated. We suspect that some bears in this study tracked the spring migration of Caribou (Rangifer tarandus), a behaviour previously suspected in northern Alaska for Barrenground Grizzlies (Reynolds and Garner 1987).

At the daily and seasonal movement rates we observed for subadult males, because of their similarity to adult male daily movement rates, it would be possible for subadult males to have home range sizes typical of male adults in the region. However, the unique feature of the subadult movements we observed appeared to be their occasional linear directionality. Other than homing behaviours of transplanted bears (Miller and Ballard 1982), extended directional movements are rare (McLellan and Hovey 2001). Explanations for longrange bear movements include seeking out quality habitat, spacing behaviour resulting from social interactions with other bears, the abundance and distribution of food (e.g., following migrating caribou herds), inbreeding avoidance, and maximizing reproductive fitness, or dispersal immediately following separation from their mother (Rogers 1987; Pasitschniak-Arts and Messier 2000). All these factors likely contributed to the movement patterns of subadult males in the Canadian central Arctic. McLoughlin et al. (1999) also pointed out that Barren-ground Grizzly Bears have larger scale movements when compared to other grizzly populations principally due to low primary productivity in the tundra environment.

The spatial behaviour of subadult male grizzlies increases their probability of coming in contact with humans even when sites of human activity (e.g., ex- 
ploration and hunting camps, industrial developments, and communities) are of considerable distance from the central home range of an individual. Subadult bears in particular do not have the life-experience of mature bears, are often imbued with more curiosity, and thus are highly susceptible to human activity. Management of bears in the central Arctic should focus on maintaining low levels of human-caused mortality of bears, with the realization that communities, hunting camps, and mining/exploration camps may impact bears from more than just the general vicinity. Also, the widespread movements of subadult bears are a compelling argument for a comprehensive and consistent bear conflict avoidance program throughout the central Arctic. Developments that might not be considered in optimum Grizzly Bear habitat should have the tools or resources to effectively manage potential problem bears.

\section{Acknowledgments}

Funding for our research was supplied by the Government of the NWT Department of Resources, Wildlife, and Economic Development, University of Saskatchewan, West Kitikmeot/Slave Society, Indian and Northern Affairs Canada, BHP Diamonds, Rescan Environmental Services, Axys Environmental Consulting Ltd., Diavik Diamond Project, Monopros Limited, Echo Bay Mines Ltd., Nunavut Wildlife Management Board, the Federal Department of Indian Affairs and Northern Development, the Northern Scientific Training Program, the Natural Sciences and Engineering Research Council of Canada, and the Polar Continental Shelf Project (number 01298).

\section{Literature Cited}

Costello, C. M., R. M. Inman, K. L. Higgins, D. E. Jones, H. B. Quigley, and S. L. Simek. 2001. Comparison of an expandable radiocollar and an eartag transmitter for monitoring juvenile black bears. Western Black Bear Workshop 7: 17.

Gau, R. J., R. Case, D. F. Penner, and P. D. McLoughlin. 2002. Feeding patterns of barren-ground grizzly bears in the central Canadian Arctic. Arctic 55: 339-344.

Government of the Northwest Territories. 2000. NWT species 2000: general status ranks of wild species in the Northwest Territories. Government of the NWT, Yellowknife, Northwest Territories. 50 pages.

Jonkel, C. J. 1987. Brown bear. Pages 457-473 in Wild Furbearer Management and Conservation in North America. Edited by M. Novak. Ontario Ministry of Natural Resources, Toronto, Ontario.

Lefranc, M. N., M. B. Moss, K. A. Patnode, and W. C. Sugg. 1987. Grizzly bear compendium. Interagency Grizzly Bear Commitee, Bozeman, Montana. 540 pages.
Mace, R. D., and J. S. Waller. 1997. Spatial and temporal interaction of male and female grizzly bears in northwestern Montana. Journal of Wildlife Management 61: 39-52.

McLellan, B. N., and F. W. Hovey. 2001. Natal dispersal of grizzly bears. Canadian Journal of Zoology 79: 838-844.

McLoughlin, P. D. 2000. The spatial organization and habitat selection patterns of barren-ground grizzly bears in Nunavut and the Northwest Territories, Canada. Ph.D. dissertation, University of Saskatchewan, Saskatoon, Saskatchewan. 151 pages.

McLoughlin, P. D., R. L. Case, R. J. Gau, S. Ferguson, and F. Messier. 1999. Annual and seasonal movement patterns of barren-ground grizzly bears in the central Northwest Territories. Ursus 11: 79-86.

McLoughlin, P. D., H. D. Cluff, R. J. Gau, R. Mulders, R. L. Case, and F. Messier. 2002. Population delineation of barren-ground grizzly bears in the central Canadian Arctic. Wildlife Society Bulletin 30: 728-737.

McLoughlin, P. D., H. D. Cluff, R. J. Gau, R. Mulders, R. L. Case, and F. Messier. 2003. Effect of spatial differences in habitat on home ranges of grizzly bears. Ecoscience 10: 11-16.

Miller, S. D., and W. B. Ballard. 1982. Homing of transplanted Alaskan brown bears. Journal of Wildlife Management 46: 869-876.

Nagy, J. A., R. H. Russell, A. M. Pearson, M. C. S. Kingsley, and C. B. Larsen. 1983. A study of grizzly bears on the barren-grounds of Tuktoyaktuk Peninsula and Richards Island, Northwest Territories, 1974-1978. Canadian Wildlife Service, Edmonton, Alberta. 127 pages.

Pasitschniak-Arts, M., and F. Messier. 2000. Brown (grizzly) and polar bears. Pages 409-428 in Ecology and Management of Large Mammals in North America. Edited by S. Demarais and P. Krausman. Prentice Hall, Englewood Cliffs, New Jersey.

Reynolds, H. V., and G. W. Garner. 1987. Patterns of grizzly bear predation on caribou in northern Alaska. International Conference on Bear Research and Management 7: 59-67.

Rogers, L. L. 1987. Effects of food supply and kinship on social behavior, movements, and population growth of black bears in northeastern Minnesota. Wildlife Monographs 97: 1-72.

Seaman, D. E., J. J. Millspaugh, B. J. Kernohan, G. C. Brundige, K. J. Raedeke, and R. A. Gitzen. 1999. Effects of sample size on kernel home range estimates. Journal of Wildlife Management 63: 739-747.

Waits, L., D. Paetkau, and C. Strobeck. 1999. Genetics of the bears of the world. Pages 25-32 in Bears: Status Survey and Conservation Action Plan. Edited by C. Servheen, S. Herrero, and B. Peyton. IUCN/SSC Bear and Polar Bear Specialist Groups, Cambridge, United Kingdom.

Woods, J. G., D. Paetkau, D. Lewis, B. N. McLellan, M. Proctor, and C. Strobeck. 1999. Genetic tagging of freeranging black bears and brown bears. Wildlife Society Bulletin 27: 616-627.

Woods, J. G., and C. Strobeck. 2000. Molecular ecology and field biology. Research Links 8: 4-9.

Received 3 February 2002

Accepted 11 November 2004 